\section{Educated Barbarism*}

Neil Rhodes, Shakespeare and the Origins of English (Oxford: Oxford University Press, 2004; paperback 2007)

It is hard to imagine an academic supervisor who would be happy to see the title of Neil Rhodes's recent book on a proposal for a doctoral dissertation. Shakespeare and the Origins of English has far too many instabilities and double meanings: as Rhodes himself explains, "Shakespeare" refers to the Elizabethan writer and also to the super-canonical product of scholarship that still "lives on" in the twenty-first century. Similarly, "English" is the vernacular that rose to literary prominence (after a protracted competition with Latin) in Shakespeare's own lifetime, but it is also convenient shorthand for "English Studies." So, the title seems to say, the book may be about several things: it may be about how Shakespeare's writings were influenced, or even made possible, by the rise of the vernacular in Renaissance England, or by his Humanist education (but did he really study "English"?), or, conversely, about how English Studies shaped, or have been shaped by, Shakespeare. The ambiguity between definiteness and plurality in "the Origins," together with the Janus-faced "and," complicate matters even further, result-

The views expressed in the book reviews do not necessarily reflect the opinions of the editors of The AnaChronisT. ing in a title that promises teleology, but has the immediate effect of disorientation - a perfect choice if not for a dissertation (luckily, Rhodes is already Professor at St. Andrews), then for a book that has something to say about all four questions mentioned above. Shakespeare and the Origins of English, as its author succinctly puts it, presents "some sort of history, though one of a rather unlinear kind" (190).

In the introduction, Rhodes calls his method historical, but one that operates "with some degree of synchronicity and anachronicity" (4). As a result, readers might approach the book in various ways: they might immerse themselves in a cultural history of Tudor rhetorical education, or read it for its acute analyses of some major Shakespeare plays

(Hamlet, Love's Labour Lost, Measure for Measure, Titus Andronicus and The Tempest receive sustained attention), or for its running argument about how English Studies might be re-conceived in the present, based on an awareness of its past, or even for its illuminating odd connections between Shakespeare and, say, Tony Harrison, "that modern barbarian" (83). There is, of course, considerable danger in writing a book of this kind, but Rhodes is as capable of tightening his logic and getting his priorities straight as of allowing himself to digress or to make an aside. The result is a readable book that wears its learning as lightly as possible; one that can be magisterial or tentative or even provocative, as occasion requires. In all this, it has 
more than a touch of the essay about it that most un-classical of Renaissance genres - and perhaps not by accident. Rhodes has called one of his previous books, The Power of Eloquence and English Renaissance Literature, a "long essay": a tentative attempt at synthesis without any pretensions to exhaustiveness. ${ }^{1}$ Even more wide-ranging than its predecessor, Shakespeare and the Origins of English shares this general stance, as well as a certain circular movement of argumentation, which likes to revisit themes and to let evidence slowly accumulate, until a more complex understanding of a question can be reached.

Rhodes's previous work is relevant because it has the subject of the present book virtually carved out in it. The Power of Eloquence was mainly concerned with classical and Renaissance ideas of eloquence as an instrument of power (with a discussion of Tudor educational programmes and the "coming of age" of the English language), and provided extensive interpretations of works by Christopher Marlowe and Ben Jonson. Which means that in that book Shakespeare was conspicuous through his absence, and a "parsimonious coda" (65) devoted to Jonson's relationship to Shakespeare even suggested "that he stands apart from the development described in the main argument" (viii). Shakespeare and the Origins of English fills the space opened up here, and it might even be fulfilling a promise made in the earlier book's coda, which was entitled "Afterword and Foreword." In other words, it is a supplement, and as such, it dutifully goes beyond what might have been expected, based on the earlier book, while it also retains vital connections with it. At one point in Eloquence, for instance, Rhodes quoted a memorable line from Emrys Jones's The Origins of Shakespeare: "without Erasmus, no Shakespeare."2 As the present title indicates, Shakespeare and the Origins of English takes Jones's position and turns it around: the book demonstrates not only how Shakespeare's Humanist education had a formative influence on his works, but also how his schooling provided him with resources for writing in English, as opposed to Latin, and how some of the educational practices he must have encountered in a Tudor grammar school fed into the later discipline of English Studies, partly through the very works he went on to write.

The last bit of this sequence is by far the most unconventional, and it yields the most illuminating type of connections established in the book. Proposing links between Tudor school practices and more or less well-known tenets of later Shakespeare criticism, Rhodes crosses a divide rarely crossed by scholars - between Renaissance studies and the study of Shakespeare's reception while he also manages to keep things properly distinct. Shakespeare, of course, did not study English, but his schooling included, among other things, the practice of double translation, which 
Rhodes links to the figure of hendiadys, so characteristic of Shakespeare's rhetoric, and, more generally, to the "double voice" critics have discovered in his plays. The fullest example of how Rhodes can establish hitherto unsuspected continuities is to be found in Chapter Three, where he tackles a characteristic feature of Shakespeare's socalled problem plays: something that has been described as the "dramatic construction of moral ambiguity" or "perspectivalism" (88) - Shakespeare's propensity for seeing things from opposing points of view. Rhodes links this to the Tudor school assignment of writing speeches "in utramque partem, on both sides of the question" (90), which had its roots in classical controversiae and compositional exercises known as the progymnasmata. These exercises, Rhodes suggests, provided opportunities for both Renaissance schoolboys and writers to explore and test power relations in a rhetorical and legal context; therefore they might be used to put into perspective more recent claims about the radical or subversive nature of Shakespeare's dramaturgy.

"Doubleness" also plays a prominent part in the next chapter, where Rhodes explores Shakespeare's ambivalent response to the classical tradition by reconstructing the cultural competition between Latin and English in the second half of the sixteenth century - a process through which the formerly "barbarous" vernacular emerged as an exceptionally well-suited vehicle for literary expres- sion, and began to be celebrated as a civilizing (and colonizing) force. Rhodes clarifies the ideological and poetic implications of blank verse in this context, and takes up Doctor Johnson's eighteenth-century insight about the heterogeneous - "hybrid" - nature of Shakespeare's tragedies. Analysing Titus Andronicus, a play rife with dislocation, which he takes to be "actually about hybridity" (140), Rhodes shows how Shakespeare both absorbed and rejected classical authority - a stance that is "reflected in double translation, double voice, and even double authorship" (148). Shakespeare's drama, in these terms, is a "strong hybrid," one that "could be described equally as neoclassical and neo-Gothic, an educated barbarism" (142). Based on this view, Rhodes argues (in opposition to Stephen Greenblatt) that even in The Tempest, Shakespeare exhibits a sense of kinship with the expressive "barbarism" of Caliban, as much as with the civilising power of Prospero. The Renaissance author whom Rhodes finds closest to this version of Shakespeare is neither Marlowe, nor Jonson, but the exuberant Thomas Nashe (in whose work he has a longstanding scholarly interest). ${ }^{3}$ Blending classical rhetoric with the fluency of vernacular speech patterns and a sense of cultural relativism, their oeuvre, for Rhodes, exemplifies "the creative abuse" of a classical education.

While these interventions in Shakespeare criticism are both provocative and well-argued, the book has another, 
more controversial line of argument, which links aspects of Elizabethan education to a range of present-day developments affecting English Studies. While far from proposing "an unbroken continuity between early modern rhetoric and modern or post-modern English" (189), Rhodes highlights "a range of literary and educational activities from the early sixteenth to the late eighteenth centuries in order to point out their similarities (as well as dissimilarities) with many of our own concerns" (190). Some of these analogies are more strategic than productive, aimed at presenting Renaissance cultural phenomena in a fresh and supposedly more interesting light. So rhetoric is figured as a Renaissance form of "media studies," while educational practices in Tudor grammar schools foster "transferable skills" and endorse "creative writing." These analogies are proposed in order to put current issues in perspective and to enable reflection on them; however, few of them are pursued in any depth. To put it simply, Rhodes is not that interested in phenomena like current "media studies," at least not in this book. At the same time, he does want to reassure "traditionalists" in English Departments that what might appear to them as a contamination or disruption of their discipline (the encroachment of media studies on "English," or the introduction of creative writing courses), has in fact deep connections with its more distant past. As he argues: "The notion that there was once a core subject which is now hopelessly splintered and diversified depends upon an artificially late date for the origins of English and a narrow formulation of what the subject comprises" (190).

"Theory" is also discussed at the beginning of the book, as something that had ushered in the transformation of English Studies from the 1970 on onwards; but Rhodes's reading of Derrida on "articulation" is far too general and simplified to vie with his sophisticated account of the vagaries of "articulation" and "expression" in Renaissance texts. 4 While clearly not a devotee of Derrida's theory, Rhodes still uncovers a number of potential connections between deconstruction and Renaissance writing, even if he does not pursue them to their logical conclusions. One connection he does pursue (although in a slightly uneasy tone) is the notion that Hamlet can be taken as a deconstruction of the revenge play (31), and, as it seems, of a whole range of concepts entrenched in Renaissance rhetoric. The play therefore "represents the first crisis in English Studies": "Although the subject had not yet been invented, the crisis, as Derrida might have said, was always already inscribed within it" (32). This intrusion of Derridean language into the texture of the book is momentary and very tentative, but in the final chapter Rhodes returns to the matter of theory more in his own vein by demonstrating how an earlier "intrusion" of French theory had been vital to the formation of English Studies. In this unusual account of the 
discipline's past, the works of Ramus and the French belles lettres tradition play a prominent role, as well as do those Scottish universities that adapted them in the later eighteenth century so, as Rhodes argues, "pace complaints from traditionalists that English was suddenly infected by new ideas from Paris in the late 1960s, it was effectively created by new ideas from Paris" (191).

Rhodes's habit of making everything sound topical - calling the revenge play a Renaissance "action movie" (38), or rhetoricians "spin doctors" (97) - can be slightly off-putting, as a number of reviewers have complained. 5 Their reaction is close to the annoyance of a student who is weary of a teacher's efforts to make the subject seem "relevant" because she is interested anyway. But the book's analogies are not all like that. For instance, the discussion of Renaissance compositional techniques in the light of computer technology yields many insights - this is an area Rhodes has been working on intensely in recent years. ${ }^{6}$ Carefully weighing differences as well as similarities, he is able to show how versions of the Renaissance "database," that is, the commonplace book and the printed anthology, influenced writing and reading practices - after they had pushed aside earlier technologies of storage and retrieval, such as the manuscript anthology and the memory theatre. Rhodes then demonstrates how Shakespeare's writings, themselves "a dizzying hypertextual world of multiple verbal links and commentary on com- mentary" (165), 7 were anthologised and "commonplaced" from the 1590 on onwards in volumes that can be regarded as the antecedents of the school textbook. This makes one realize that such notorious 18th-century compilations as the Elegant Extracts, or the Beauties of Shakespeare - so often criticised by their Romantic readers - were in fact closer to Shakespeare's own rhetorical context than their later detractors, who tended to prize a play's organic unity (at least in theory) above the detachable textual unit.

Rhodes's discussion ends at the threshold of Romanticism, when, in the second half of the eighteenth century, Shakespeare was recast as "the dramatist of the passions" (212) in the writings of William Richardson and Lord Kames, among others. In a gesture that might be suggestive of a next book, he remarks that the tradition he has been tracing does not stop there: "The story of the Romantic reception of Shakespeare ... is well known, but the present discussion provides other leads into that culturally transforming phenomenon" (225). Taking a look at some wellknown passages by Coleridge with that suggestion in mind, one finds much to corroborate the general point. In Chapter 15 of the Biographia Literaria, for instance, discussing Shakespeare's poetic genius, Coleridge quotes a sentence that also appears briefly in Rhodes's discussion of the commonplace method: "Inopem me copia fecit," "plenty has made me poor" - a quotation from a 
passage in Ovid's Metamorphosis where Narcissus, enamoured with his own reflection, is about to commit suicide. ${ }^{8}$ It is tempting to take this Ovidian moment as expressive of a typically Romantic attitude to Shakespeare: the critic looks into Shakespeare's mirror, and sees himself. Or, conversely, trying to see himself, he finds Shakespeare instead (Coleridge surely had a "smack of Hamlet," after all). Narcissus's despair might even be linked to the Romantics' sense of their own "poverty" in the face of Shakespeare's "plenty." While these suggestions are all perfectly in line with well-worn ideas about the "Romantic Shakespeare," the context that Rhodes has so meticulously established might also make one alert to the rhetorical groundwork of Coleridge's passage, which might then lead to slightly different emphases.

Coleridge in the Biographia passage is not only quoting a Latin locus communis, but does so in order to give his readers a sense of Shakespeare's copia, or plenty, when looking around for examples of how poetic imagery "moulds and colours itself to the circumstances, passion, or character, present and foremost in the mind" (190). Now, copia is a key concept of Erasmian rhetoric, which, as Rhodes has shown through various examples, informed both Shakespeare's works and their reception, while "circumstances," "passion," and "character" are all technical terms in eighteenthcentury rhetoric, based on Quintilian's discussions of how language can move its listeners. ${ }^{9}$ These terms were also used in various 18th-century descendants of the anthology which often listed passages from Shakespeare's plays according to the different passions they illustrated (Rhodes remarks that Burgh's Art of Speaking, for instance, contains a "comprehensive table of the passions, where they have the status of topics or commonplaces," 187). So, when Coleridge adds that "the reader's own memory will refer him" to the "unrivalled instances of this excellence" (190) in Shakespeare's plays, one might suspect that, while speaking of an interiorized corpus, Coleridge is also informed by the long tradition of the anthology and its later descendants, as reconstructed in Rhodes's rich and suggestive book. Romantic readers, it may be argued, did not invent their own Shakespeare from scratch - sometimes they worked with the memory of an already "commonplaced" author, whose "excellence" at drawing various passions and characters had been helpfully catalogued by earlier critics and anthologists. While an inquiry into these issues clearly falls outside the scope of the book, it is probably safe to suggest that Shakespeare and the Origins of English will keep provoking and inspiring not only Renaissance scholars, but all kinds of students of all kinds of "Englishes."

Veronika Ruttkay

Notes

* The writing of this review was funded by the EEA and Norway Grants, through the Magyary Zoltán Postdoctoral Fellowship. 
1. Rhodes, The Power of Eloquence and English Renaissance Literature (Hemel Hempstead: Harvester Wheatsheaf, 1992), p. viii.

2. Emrys Jones, The Origins of Shakespeare (Oxford: Clarendon, 1977), p. 13. Quoted in Rhodes, The Power of Eloquence, p. 51.

3. Nashe is linked to Shakespeare in Rhodes's book Elizabethan Grotesque (London: Routledge and Kegan Paul, 1980).

4. Juliet Fleming in her review essay has criticised Rhodes for misreading Derrida; see “An Apology for Reading," Modern Philology 104.2 (November 2006) 229-38.

5. See for instance Ralph Berry in the Contemporary Review, 286/1671 (April 2005) 245-6; Russ McDonald in the Shakespeare Quarterly, 57/3 (Fall 2006), 351-4; John Lee in Modern Language Review 101/3 (July 2006) 822-4.

6. See The Renaissance Computer: Knowledge Technology in the First Age of Print, ed. Rhodes and Sawdy (London: Routledge, 2000), or a brilliant recent article on how Marshall McLuhan's doctoral dissertation on Thomas Nashe fed into his later and more well-known writings: "On Speech, Print, and New Media: Thomas Nashe and Marshall McLuhan," in Oral Tradition 24.2 (October 2009). Cf. Rhodes, "Mapping Shakespeare's Contexts: Doing Things With Databases," in Andrew Murphy ed., A Concise Companion to Shakespeare and the Text (Blackwell, 2007), 204-220.

7. Rhodes uses this phrase to describe The Sonnets, but it seems expressive of his general view of Shakespeare's textual universe.

8. S. T. Coleridge, Biographia Literaria, ed. Nigel Leask (London: J. M. Dent \& Vermont: Charles E. Tuttle, 1997), p. 190.

9. Klaus Dockhorn has discussed the comparable sequence of "passions, characters, incidents" as well as the concept of "circumstances" in Wordsworth's writings in the context of classical rhetoric in "Wordsworth and the Rhetorical Tradition in England" (1944), trans. Heidi I. Saur-Stull, in Don H. Bialostosky and Lawrence C. Needham ed., Rhetorical Traditions and British Romantic Literature (Bloomington and Indianapolis: Indiana UP, 1995), 265-280, p. 270.

\section{Keats Posthumously Personalized}

Stanley Plumly, Posthumous Keats: A

Personal Biography (New York \&

London: W. W. Norton, 2008)

“A Man's Life of any worth is a continual allegory - and very few eyes can see the Mystery of his life," wrote Keats to his brother George in the spring of 1819. ${ }^{1}$ Stanley Plumly's magnificent book, pursuing the mystery of how the poet's immortality is achieved, is perhaps more respectful of what Keats worded as the figurative aspect of one's life than any other biography. The essays, though rich in suggestions, admit again and again the need to be able to remain in uncertainties about how much we can know. Plumly's speculations about the importance and rich ambiguities of the images of mist and veiling in Keats's poetry are brilliant in this respect. Commenting on passages from Endymion, The Fall of Hyperion, "To Autumn," and the letters, Plumly writes that air is the medium of transformation and disappearance for Keats, the means of "erasure, chameleon 